\section{KẾT LUÂ̂N}

1. Tải lượng HBV DNA và hoạt độ ALT huyết thanh ở bệnh nhân VGBMT

- Tải lượng HBV DNA trung bình của nhóm bệnh nhân nghiên cứu là $1,2 \times 10^{8} \pm 0,7 \times 10^{7}$ copies $/ \mathrm{mL}$ (cao nhất là $1,5 \times 10^{9}$ copies $/ \mathrm{mL}$ và thấp nhất là 140 copies $/ \mathrm{mL}$ ). Trong đó tải lượng HBV DNA ở những bệnh nhân có $\mathrm{HBeAg}(+) /$ AntiHBe(-) là $3,1 \times 10^{8} \pm 1,2 \times 10^{8}$ cao hơn có ý nghĩa thống kê so với nhóm bệnh nhân $\mathrm{HBeAg}(-)$ /AntiHBe(+) là $2,9 \times 10^{7} \pm 0,4 \times 10^{7}$ (với $p<0,05$ )

- Hoạt độ ALT huyết thanh trung bình của các bệnh nhân nghiên cứu là 561,94 \pm 207,19 U/L. Khi so sánh hoat độ ALT huyết thanh trung bình của hai nhóm bệnh nhân có $\mathrm{HBV}$ DNA $\geq 300$ và $<300$ copies $/ \mathrm{mL}$, chúng tôi nhận thấy rằng hoạt độ ALT ở nhóm bệnh nhân HBV DNA $\geq 300$ copies/mL là $572,78 \pm 180,9 \mathrm{U} / \mathrm{L}$ cao hơn có ý nghĩa thống kê với nhóm bênh nhân có $\mathrm{HBV}$ DNA < 300 copies $/ \mathrm{mL}$ là $150 \mathrm{U} / \mathrm{L}$.

2. Mối tương quan giữa tải lượng $\mathrm{HBV}$ DNA và hoạt độ ALT huyết thanh ở bệnh nhân VGBMT. Trong nghiên cứu bước đầu của chúng tôi, chưa có mối tương quan có ý nghĩa thống kê nào giữa giữa tải lượng HBV DNA huyết thanh với hoạt độ ALT huyết thanh ở các bệnh nhân VGBMT nói chung $(r=-0,12 ; p=0,46)$ cũ̃ng như từng nhóm bệnh nhân nói riêng.

\section{TÀI LIÊU THAM KHẢO}

1. Đỗ Tuấn Anh (2012), "Nghiên cứu mối liên quan giữa tải lượng vi rút với một số biểu hiện lâm sàng và xét nghiệm chức năng gan ở bệnh nhân viêm gan vi rút $B$ man tính", Y hoc thức hành. 843, 62-65.

2. Nguyến Đức Cường và Đồ Quốc Tiệp (2017), "Thực trang nhiếm vi rút viêm gan $B$ trong cộng đồng dân cư tỉnh Quảng Bình năm 2017", Tạp chi thông tin khoa học và công nghệ Quảng Bình. 4, 76-82.

3. Nguyễn Văn Dũng (2015), Đặc điểm dịch tễ, sinh hoc phân tứ, lâm sàng, cân lâm sàng và yếu tố ảnh hưởng điếu trị đến hiệu quả điều trị viêm gan vi rút $\mathrm{B}$ mạn bằng thuốc kháng vi rút, Luận án Tiến sỹ, Viên Về sinh Dich tễ Trung ương, Hà Nôii.

4. Đình Văn Huy (2012), Đánh giá kết quả điêuu trị của tenofovir trên bênh nhân viêm gan vi rút $B$ mạn tại Bệnh viện Bệnh Nhiệt đới Trung ương, Luận vằn Thạc sỹ $Y$ học, Học viện Quân $y$, Hà Nội.

5. Ngô Viết Lộc (2012), Nghiên cứu tình hình nhiềm vi rút viêm gan $B$ và đánh giá kết quả can thiêp công đồng taii môt số xã, phường tỉnh Thừa Thiển Huêe, Luận án Tiến sỹ Y hoc, Đại học Y - Dược Huế

6. Đố Thị Lê Quyên (2015), Đánh giá đáp ứng điều trị với Entecavir ở bệnh nhân viêm gan vi rút $B$ man tính hoạt động có $\mathrm{HBeAg}$ dương tính và âm tính, Luân văn Thac sỹ Y hoc, Hoc viên Quân y, Hà Nội.

7. Nguyền Hữu Quyên (2015), Nghiên cứu nồng đô HBSAg, tải lương vi rút và hoạt độ ALT huyết tương ở các thể lầm sàng nhiễm vi rút viêm

8. World Health Organization (WHO) (2012) Prevention and control of viral hepatitis infection: framework for global action., WHO, Geneva.

\title{
YẾU TỐ LIÊN QUAN VỚI SỰ TUÂN THỦ ĐIỀU TRI Ở NGƯờI BỆNH TĂNG HUYẾT ÁP ĐIỀU TRI NGOẠI TRÚ
}

\section{TÓM TẮT}

Cơ sở nghiên cứu: sự tuân thủ điều trị quyết định sự thành công của việc điều trị bệnh tăng huyết áp. Mục tiêu: tìm hiểu một số yếu tổ liên quan với tình trạng tuân thủ điêu trị ở người bệnh tăng huyết áp ngoại trú. Đối tượng và phương pháp: Nghiên cứu được thực hiện tại phòng khám ngoại trú tuyến cơ sở. Các yếu tố liên quan được đánh giá bao gồm tuổi, giới, trình độ học vấn, số thuốc sử dụng, bệnh

\footnotetext{
${ }^{1}$ Trung tâm Y tế - Môi trường lao động Công thương ²Bênh viện Lão khoa Trung ương

${ }^{3}$ Trường Đại học Y Hà Nội

${ }^{4}$ Trung tâm Chống độc - Bệnh viện Bạch Mai

Chịu trách nhiệm chính: Nguyễn Trung Anh

Email: trunganhvlk@gmail.com

Ngày nhận bài: 5.01.2021

Ngày phản biện khoa học: 3.3.2021

Ngày duyệt bài: 12.3.2021
}

\author{
Đào Văn Cường1, Nguyễn Ngọc Tâm ${ }^{2,3}$, \\ Đặng Thị Xuân ${ }^{4}$, Nguyễn Trung Anh ${ }^{2,3}$
}

mắc kèm. Mối liên quan với đạt huyết áp mục tiêu được đánh giá. Kết quả: Các nhóm tuổi trên có sư đồng đều về tuân thủ thuốc: nhóm tuổi từ 40-60 tuổi là $72,6 \%$, nhóm tuổi $61-75$ tuổi là $71,3 \%$, nhóm tuối $\geq 75$ tuổi là $69,2 \%$. Tuân thủ tốt ở nhóm điêuu trị THA đơn độc là $71,4 \%$, tuân thủ tốt ở nhóm mắc kèm thêm 01 bênh là $72,5 \%$, tuân thủ tốt ở nhóm mắc kèm thêm 02 bệnh là $66,7 \%$. Tỷ lệ bệnh nhân tuân thủ tốt đạt mục tiêu huyết áp là $53,5 \%$, tuân thủ tốt không đạt mục tiêu 18,1\%. Kết luận: Một số yếu tố liên quan tới sự tuân thủ thuốc là số thuốc huyết áp phải sử dụng, số bệnh mắc kèm theo. Tuân thủ thuốc tốt liên quan tới đạt muc tiêu điều trị tốt hơn.

Tư khóa: tăng hyểt áp,tuân thủ, yếu tố liên quan.

\section{SUMMARY}

RELATED FACTORS WITH MEDICATION ADHERENCE OF HYPERTENSIVE OUTPATIENTS

Background: The medication adherence decide the effect on hypertensive treatment. Objectives: To 
determine some related factors with medication adherence of hypertensive outpatients. Subjects and Methods: The study was conducted at general healthcare center. Some related factors was assessed, including, age, gender, educational level, number of hypertensive medications, co-morbidities. The relationship between medication adherence and hypertensive treatment target was evaluated. Results: According to aged groups, proportion of adherence was similar, 40-60 years: $72.6 \%$, $61-75$ years: $71.3 \%, \geq 75$ years: $69.2 \%$. The rate of good adherence was $71.4 \%$ on hypertensive patients without co-morbidity, $72.5 \%$ and $66,7 \%$. in patients having one and two co-morbidities, respectively. $53.5 \%$ and $18.1 \%$ of study population reach the hypertensive treatment target in good adherence and bad adherence group, respectively. Conclusion: Number of hypertensive medication and co-morbidities were related with treatment adherence. Good medication adherence was related with having blood pressure in treatment target range.

Keywords: Hypertension, adherence, related factors.

\section{I. ĐẶT VẤN ĐỀ}

Điều trị và kiểm soát tăng huyết áp (THA) gồm sử dụng thuốc và không dùng thuốc $[1,4]$. hiệu quả điều trị được quyết định bởi sự tuân thủ điêu trị bao gồm sử dụng thuốc và tái khám định kì $[1,4]$. Có nhiều phương pháp có thể sử dụng để đánh giá sự tuân thủ điêu trị ở người bệnh THA. Trong đó, bộ câu hỏi Morisky là phương pháp đánh giá dễ thực hiện và có thể sử dụng rộng rãi [5]. Độ nhạy và độ đặc hiệu của thang Morisky-8 đối với bệnh nhân tăng huyết áp là $93 \%$ và $53 \%$. Do đó, thang Morisky-8 là thang đánh giá dựa trên báo cáo của bệnh nhân được chấp nhận và sử dụng nhiều trong thực hành lâm sàng. Bộ câu hỏi này đã được đánh giá giá trị và áp dụng tại Việt Nam [6].

Có nhiều yếu tố ảnh hưởng tới tuân thủ sử dụng thuốc trên bệnh nhân tăng huyết áp,yếu tố liên quan đến bệnh tật, Yếu tố liên quan đến bệnh nhân, yếu tố từ nhân viên y tế, điều trị và yểu tố kinh tế xã hội, hệ thống chăm sóc sức khỏe cho bệnh nhân. Việc xác định các yếu tố này giúp cho các nhà thực hành lâm sàng dễ dàng hơn trong việc nâng cao sự tuân thủ điều trị của bệnh nhân. Và từ đó nâng cao hiệu quả điều trị ở người bệnh THA. Vì vậy, chúng tôi tiến hành đề tàivới mục tiêu tìm hiểu một số yếu tố liên quan với tình trạng tuân thủ điều trị ở người bệnh tăng huyết áp ngoại trú.

II. ĐỐI TƯỢNG VÀ PHƯƠNG PHÁP NGHIÊN CứU

2.1 Đối tượng nghiên cứu. Người bệnh THA được quản lý, điều trị ngoại trú và có hồ sơ quản lý bệnh mạn tính đồng ý tham gia vào nghiên cứu.
2.2 Địa điểm và thời gian thực hiện nghiên cứu:

+ Địa điểm: Phòng khám đa khoa - Trung tâm Y tế - Môi trường lao động công thương, 99 Văn cao

+ Thời gian: từ 01/6/2019 đến 31/12/2019

2.3 Phương pháp nghiên cứu

Thiết kế nghiên cứu: Nghiên cứu mô tả cắt ngang

Công cụ thu thập số liệu:

+ Bênh án nghiên cứu

+ Hồ sơ bênh án ngoai trú.

Các biến số nghiên cứu và cách đánh giá

- Tuân thủ sử dụng thuốc:

Tuân thủ sử dụng thuốc của bệnh nhân được đánh giá theo thang Morisky-8. Sau khi thực hiện bộ câu hỏi, mức độ tuân thủ được phân loại dựa vào tổng điểm: 7 - 8 điểm: tuân thủ tốt; $\leq 6$ điểm: tuân thủ kém.

- Các yếu tố liên quan

Các yếu tố liên quan tới tình trạng tuân thủ thuốc điều trị THA bao gồm:

- Tuổi: chia làm 3 nhóm 40 - 60 tuổi, 61 - 75

tuổi và > 75 tuổi

- Giới: nam/ nữ

- Trình đô̂ hoc vấn

- Nghề nghiểp

- Số nhóm thuốc sử dụng điều trị THA: dựa vào Hồ sơ ngoại trú, loại thuốc và nhóm thuốc điều trị THA được thu thập

Số bệnh mắc kèm: Các bệnh (Đái tháo đường, rối loạn Lipid máu, suy tim, viêm cầu thận mạn, tai biến mạch não) được đánh giá và khai thác. Từ đó số bệnh mắc kèm THA được xác đinh.

Xử lý số liệu

- Nhập liệu bằng Redcap, Trường Đại học $Y$ Hà Nội (http://redcap.hmu.edu.vn/)

- Xử lý số liệu trên phần mềm SPSS 20.0.

III. KẾT QUẢ NGHIÊN CứU

Bảng 3.1. Mối liên quan giữa tuân thủ sử dụng thuốc và một số đặc điểm chung

\begin{tabular}{|c|c|c|c|}
\hline \multicolumn{2}{|c|}{ Đặc điểm } & $\begin{array}{c}\text { Tuân thủ } \\
\text { tốt (\%) }\end{array}$ & $\begin{array}{c}\text { Tuân thủ } \\
\text { kém(\%) }\end{array}$ \\
\hline \multirow{2}{*}{ Giới } & Nam & 74,6 & 25,4 \\
\cline { 2 - 4 } & Nữ & 69,8 & 30,2 \\
\hline \multirow{3}{*}{ Tuổi } & Từ 40 - 60 tuối & 72,6 & 27,4 \\
\cline { 2 - 4 } & Từ 61 - 75 tuối & 71,3 & 28,8 \\
\cline { 2 - 4 } & $\geq 75$ tuối & 69,2 & 30,8 \\
\hline \multirow{2}{*}{$\begin{array}{c}\text { Trình độn } \\
\text { học vấn }\end{array}$} & $\begin{array}{c}\text { Không đi học/ } \\
\text { Mù chữ }\end{array}$ & 50 & 50 \\
\cline { 2 - 4 } & Cấp 1, Cấp 2, cấp 3 & 72,6 & 27,4 \\
\cline { 2 - 4 } & Cao đằng trở lên & 57,1 & 42,9 \\
\hline
\end{tabular}




\begin{tabular}{|c|c|c|c|}
\hline \multirow{3}{*}{$\begin{array}{c}\text { Nghề } \\
\text { nghiệp }\end{array}$} & $\begin{array}{c}\text { Cán bộ viên chức, } \\
\text { công nhân }\end{array}$ & 72,2 & 27,8 \\
\cline { 2 - 4 } & Hưu trí, già yếu & $66,0 \%$ & $34,0 \%$ \\
\cline { 2 - 4 } & $\begin{array}{c}\text { Nông dân, tự do, } \\
\text { nội trợ... }\end{array}$ & $75,0 \%$ & $25,0 \%$ \\
\hline
\end{tabular}

Nhìn chung sự tuân thủ sử dụng thuốc tăng huyết áp trên cả giới tính nam và nữ tương đương nhau: nam tuân thủ tốt $74,6 \%$, nữ tuân thủ tốt $69,8 \%$.

Qua bảng trên ta nhận thấy ở các nhóm tuổi trên có sự đồng đều vể tuân thủ thuốc: nhóm tuổi từ 40-60 tuổi là 72,6\%, nhóm tuổi 61-75 tuổi là $71,3 \%$, nhóm tuối $\geq 75$ tuổi là 69,2\%.

Bảng 3.2. Đặc điểm số thuốc sử dụng với việc tuân thủ sử dụng thuốc

\begin{tabular}{|c|c|c|}
\hline Đặc điểm & $\begin{array}{c}\text { Tuân thủ } \\
\text { tốt }\end{array}$ & $\begin{array}{c}\text { Tuân thủ } \\
\text { kém }\end{array}$ \\
\hline Sử dụng 01 thuốc & $68,8 \%$ & $31,2 \%$ \\
\hline Sứ dụng 02 thuốc & $74,3 \%$ & $25,7 \%$ \\
\hline Sử dụng 03 thuốc & $71,4 \%$ & $28,6 \%$ \\
\hline Sứ dụng 04 thuốc & $100 \%$ & $0 \%$ \\
\hline
\end{tabular}

ớ đây sự liên quan giữa số lượng thuốc điều trị huyết áp cũng ảnh hưởng lớn tới sự tuân thủ thuốc điều trị huyết áp cu thể: tuân thủ thuốc tốt ở nhóm chỉ sử dụng 01 loại thuốc $68,8 \%$, tuân thủ thuốc tốt ở nhóm chỉ sử dụng 02 loại thuốc $74,3 \%$, trong khi đó sự tuân thủ thuốc tốt ở nhóm sử dụng 03 hoặc 04 loại thuốc điều trị tăng huyết áp rất thấp lần lượt là $71,4 \%$ và $100 \%$.

Bảng 3.3. Đăc điểm số bênh mắc kèm với việc tuân thử sử dụng thuốc

\begin{tabular}{|c|c|c|}
\hline Đặc điểm & $\begin{array}{c}\text { Tuân thủ } \\
\text { tốt }\end{array}$ & $\begin{array}{c}\text { Tuân thủ } \\
\text { kém }\end{array}$ \\
\hline THA đơn độc & $71,4 \%$ & $28,6 \%$ \\
\hline Mắc kèm 01 bệnh & $72,5 \%$ & $27,5 \%$ \\
\hline Mắc kèm 02 bệnh & $66,7 \%$ & $33,3 \%$ \\
\hline Mắc kèm 03 bệnh & $100 \%$ & $0 \%$ \\
\hline Mắc kèm 04 bệnh & 0 & $100 \%$ \\
\hline
\end{tabular}

Việc điều trị các bênh mắc thêm kèm theo với việc điều trị THA cũng ảnh hướng lớn đến sự tuân thủ thuốc điều trị THA cụ thể: tuân thủ tốt ở nhóm điều tri THA đơn độc là $71,4 \%$, tuân thủ tốt ở nhóm mắc kèm thêm 01 bênh là $72,5 \%$, tuân thủ tốt ở nhóm mắc kèm thểm 02 bênh là $66,7 \%$, tuân thủ tốt ở nhóm mắc kèm thểm 03 bệnh là $100 \%$, tuân thủ tốt ở nhóm mắc kèm thêm 04 bênh là $0 \%$,

Đặc điểm bệnh nhân đạt huyết áp mục tiêu với sự tuân thủ thuốc điều trị tăng huyết áp được thể hiện dưới biểu đồ sau sau:

Đăc điểm liên quan giữa việc tuân thủ thuốc với huyết áp đạt mục tiêu: tuân thủ tốt đạt mục tiêu $53,5 \%$, tuân thủ tốt không đạt mục tiêu $18,1 \%$, tuân thủ kém đạt mục tiêu $20 \%$, tuân thủ kém không đạt mục tiêu 8,4\%.

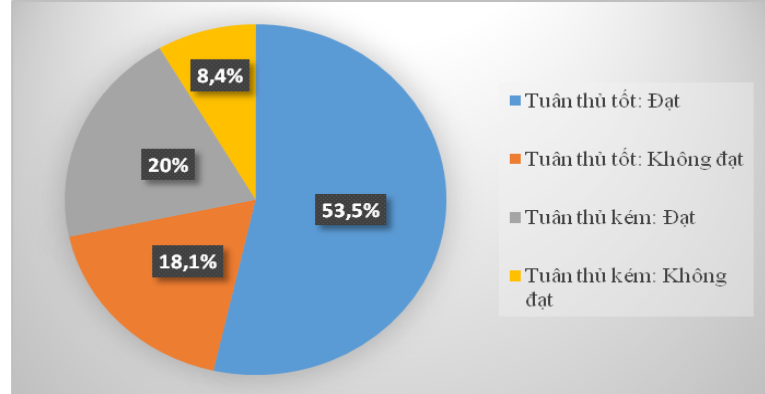

Biểu đồ 3.1. Đặc điểm đạt huyêt áp mục tiêu với sự tuân thủ thuốc

\section{BÀN LUẬN}

Morisky là bộ câu hỏi tự điền, về mặt nguyên tắc, bộ câu hỏi được gử đến bệnh nhân để họ tự điền và sau đó được thu lại để tổng hợp kết quả. Tuy nhiên, do đối tượng nghiên cứu ở đây hầu hết đã có tuổi, do vậy để hạn chế sai sót do bệnh nhân không thực sự hiểu câu hỏi, nhóm nghiên cứu đã tự phỏng vấn và làm rõ câu hỏi cho bênh nhân hiểu trước khi trả lời câu hỏi.

Việc tuân thủ thuốc điều trị THA phụ thuộc vào rất nhiêu yếu tố liên quan từ kết quả nghiển cứu trên có thể nhận xét các vấn đề liên quan. Chúng tôi không nhận ra được sự liên quan của: tuổi, giới tính, trình độ học vấn, công việc hiện tại, số thuốc huyết áp phải sử dụng, số bệnh mắc kèm với việc tuân thủ sử dụng thuốc. Kết quả nghiên cứu cũng tương đồng với một số tác giả khác tại Việt Nam.

Nghiên cứu của tác giả Ngô Quốc Huy sử dụng bộ câu hỏi Morisky-8 trên 282 bệnh nhân tai câu lac bô THA bênh viện đa khoa Đống Đa, Hà Nội thu được kết quả: tỷ lệ bệnh nhân tuân thủ sử dụng thuốc là $65 \%$. Các yểu tố liên quan đến tuân thủ sử dụng thuốc gồm: tham gia sinh hoat tư vấn sử dụng thuốc, xử trí các tác dụng phụ, sử dụng 1 thuốc điều trị THA và sử dụng thuốc 1 lân trong ngày. Tuân thủ sử dụng thuốc có ảnh hưởng tới huyết áp mục tiêu của bệnh nhân [2].

Nghiên cứu của Nguyễn Thị Mỹ Hạnh và cộng sự trên 350 bệnh nhân THA tại Bệnh viện Trưng Vương sử dụng bộ câu hỏi Morisky-8. Tỷ lệ tuân thủ sử dụng thuốc của bệnh nhân tăng huyết áp là $69,4 \%$ tỷ lệ đạt huyết áp mục tiêu là $46 \%$. Nghiên cứu có chỉ ra mối liên quan giữa sự tuân thủ dùng thuốc với các yếu tố như: tuối, thời gian điều trị THA và mắc kèm đái tháo đường. Tuy nhiên, tác giả không nhận thấy mối liên quan giữa tuân thủ sử dụng thuốc với kiểm soát huyết áp của bệnh nhân [3]. 
Nghiên cứu chỉ ra được một số yếu tố ảnh hưởng tới tuân thủ sử dụng thuốc của một số bệnh nhân như: kiến thức về bệnh, biến cố bất lợi trong quá trình điều trị. Qua đó, Trung tâm có thể thực hiện các biện pháp can thiệp nhằm nâng cao tuân thủ sử dụng thuốc của bệnh nhân hơn nữa và duy trì được tình hình tuân thủ sử dụng thuốc như tại thời điểm chúng tôi tiến hành nghiên cứu.

\section{KẾT LUẬN}

Một số yếu tố liên quan tới sự tuân thủ thuốc là số thuốc huyết áp phải sử dụng, số bệnh mắc kèm theo. Tỷ lệ bệnh nhân đạt huyết áp mục tiêu của việc tuẩn thủ sử dụng thuốc tốt cao gấp 2,7 lân so với bệnh nhân tuân thủ sử dụng thuốc kém.

\section{TÀI LIÊU THAM KHẢO}

1. Hội tim mạch hoc Quốc gia Viêt Nam (2018) "Khuyến cáo về chẩn đoán và điểu trị tăng huyết áp 2018".

2. Ngô Quốc Huyy (2014), Mô tả kiến thức, thực hành và các yếu tố liên quan đến tuân thủ điều trị của bênh nhân tai câu lạc bộ tăng huyết áp bệnh viện đa khoa Đổng Đa, Hà Nội 2014, Luận văn
Thạc sĩ Quản lý bệnh viện, Trường Đại học $Y$ tế công công, Hà Nôii.

3. Nguyến Thị Mỹ Hanh, Nguyễn Thị Mỹ Duyên (2013), "Khảo sát mối liên quan giữa tuân thủ dùng thuốc và kiểm soát huyết áp ở bệnh nhân tăng huyết áp đang điều trị ngoại trú", Hội nghị khoa học kỹ thuật Bệnh viện cấp cứu Trưng Vương.

4. Whelton PK, Carey RM, Aronow WS, Casey DE, Collins KJ, Himmelfarb CD, DePalma SM, Gidding $S$, Jamerson KA, Jones DW: 2017ACC/ AHA/AAPA/ABC/ACPM/AGS/APhA/ASH/ASPC/NMA/ PCNA guideline for the prevention, detection, evaluation, and management of high blood pressure in adults: a report of the American College of Cardiology/American Heart Association Task Force on Clinical Practice Guidelines. Journal of the American College of Cardiology 2018, 71(19):e127-e248.

5. Lam WY, Fresco P: Medication adherence measures: an overview.BioMed research international 2015, 2015.

6. Nguyen T, Cao HT, Quach DN, Le KK, Au SX, Pham ST, Nguyen TH, Pham TT, Taxis K: The Vietnamese Version of the Brief Illness Perception Questionnaire and the Beliefs about Medicines Questionnaire: Translation and Cross-cultural Adaptation.Tropical Medicine \& International Health 2019, 24(12):1465-1474.

\section{U DÂY THẦN KINH SỐ VIII DANG NANG: KẾT QUẢ ĐIỀU TRI PHẪU THUẬT TẠI BỆNH VIỆN VIỆT ĐỨC}

\section{TÓM TẮT}

Muc tiêu Đánh giá kết quả điều trị phẫu thuật u dây thần kinh số VIII dang nang. Đối tượng và phương pháp nghiên cứu: Nghiên cứu hồi cứu 35 trường hợp u dây VIII dạng nang được điều trị phẫu thuât tai bênh viện Viêtt Đức từ 1.2017 đến 6.2020 .

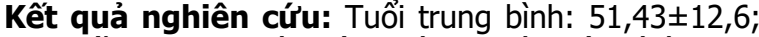
nữ chiếm $37,14 \%$ và không có sự khác biệt có ý nghĩa thống kê về giới. Ù tai là triệu chứng thường gặp nhất $(85,71 \%) ;$ có $5,71 \%$ trường hợp liệt măt trước mổ. Có 16 bệnh nhân $(45,71 \%)$ u ở độ III và IV theo phân độ KOOS. Kích thước trung bình của u là $38,35 \pm 6,25$ (mm). Phẫu thuật với đường mổ sau xoang sigma $(77,14 \%)$ là phưởng pháp mổ chính. Kết luận: Không có sự khác biệt về triệu chứng lâm sàng của u dây VIII dạng nang với các u dây VIII khác. Phẫu thuật với đường mổ sau xoang sigma là phương pháp an

\footnotetext{
${ }^{1}$ Bệnh viện Việt Đức

${ }^{2}$ Đại họ Y Hà nọi

Chiu trách nhiệm chính: Ngô Manh Hùng

Email: ngomanhhung2000@gmail.com

Ngày nhận bài: 6.01.2021

Ngày phản biện khoa học: 4.3.2021

Ngày duyệt bài: 15.3.2021
}

Ngô Mạnh Hùng1, Nguyễn Đức Nghĩa ${ }^{2}$

toàn, có hiệu quả cả về mức độ lấy u và chức năng thần kinh mặt.

Tư khoá: u dây thần kinh số VIII; u dạng nang; kết quả điều trị phẫu thuật

\section{SUMMARY}

THE CYSTIC ACOUSTIC NEUROMA: SURGICAL RESULTS AT VIET-DUC HOSPITAL

Objective: Assesment of surgical results of the cystic acoustic neuroma. Patients and methods: A cross-section, descriptive and retrospective study with 35 patients who were diagnosed, surgically treated of cystic acoustic neuroma at Viet-Duc hospital from Jan 2017 to June 2020. Results: mean age: $51.43 \pm 12.6$ (years); female $(37.14 \%)$ and there was no significant difference between the male and the female. Tinnitus was the most common symptoms $(85,71 \%)$ and there was 5.71 percent of patients with facial palsy at diagnosis time. There were sixteen patients $(45.71 \%)$ of tumor in grade III and IV of KOOS grade classification. The mean diametter of tumors was $38.35 \pm 6.25(\mathrm{~mm})$. The most patients were operated with retrosigmoid approach. Conclusion: There was no difference in the symptoms in the cystic acoustic neuroma compared the acoustic neuroma. The retrosigmoid approach was the usefulnes and safely procedure, both the level of remove of tumor and 